\title{
An Assay of some Thermal Characteristics, Chemical and Phytochemical Constituents of Hymenocarida Acida Timber
}

\section{${ }^{* 1}$ UDEOZO, IP; ${ }^{2}$ EJIKEME, CM; ${ }^{3}$ EBOATU, AN; ${ }^{4}$ KELLE, HI}

\author{
${ }^{1}$ Department of Chemistry, Tansian UniversityUmunya, Anambra State, Nigeria \\ ${ }^{2}$ Chemical Science Department, Godfrey Okoye University, Enugu, Enugu State, Nigeria \\ ${ }^{3}$ Pure and Industrial Chemistry Department NnamdiAzikiwe University Awka, Anambra State \\ ${ }^{4}$ Chemistry Unit, National Open University of Nigeria, Victoria Island, Lagos, Nigeria.
}

\begin{abstract}
Timber has always played an influencing role in human lives. The quality of timber and its behavior in response to fire depends on many parameters. As a result Hymenocardiaacidawood was studied in terms of thermal, chemical, physical and variable techniques. The results obtained were as follows: afterglow time 58.33sec, flame duration $271.67 \mathrm{sec}$, flame propagation rate $4.4 \times 10^{-2} \mathrm{~cm} \cdot \mathrm{s}^{-1}$, ignition time $3.67 \mathrm{sec}$, thermal conductivity $14.37 \mathrm{x}$ $10^{2} \mathrm{Umoh} / \mathrm{cm}$, electrical conductivity $4.4 \times 10^{-3} \mathrm{Sm}^{-1}$, ash content $0.95 \%$, moisture content $12.67 \%$, oven dry density $78.7 \times 10^{-2}{\mathrm{~g} . \mathrm{cm}^{-3}}^{-3}$, water imbibitions (at different time intervals: 30mins $11.1 \%$, 5hrs $13.8 \%$ and $24 \mathrm{hrs} 22.3 \%$ ), etc, These results showed it to be a good timber suitable for various construction purposes. Phytochemical screening showed the presence of saponins, tannins, steroids, flavonoids, carbohydrates, proteins, resins, terpenoids, glycosides and alkaloids. The Atomic Absorption Spectrophotometer (AAS) of the sample showed the presence of some metals such as $\mathrm{Na}, \mathrm{K}, \mathrm{Pb}, \mathrm{Ca}, \mathrm{As}, \mathrm{Zn}, \mathrm{Mg}$, and $\mathrm{Cu}$ in the decreasing order of their concentrations. The thin layer chromatographic analysis of the chloroform and chloroform-methanol extracts which gave three spots with Rf values of $0.7,0.6$ and 0.5 was further characterized using Fourier Transform Infrared and Ultraviolet Spectroscopic methods. The Fourier Transform Infrared and Ultraviolet spectra suggested a 1,2,3-trisubstitutedphenylamide with $\mathrm{OH}, \mathrm{CO}$ and $\mathrm{CN}$ groups attached as the functional groups present. The chemical components analysis showed the presence of cellulose, hemicelluloses, lignin and other constituents in their right proportion. The results provided the required information on the properties of Hymenocardiaacidawood. It also confirmed the efficiency of the wood for various construction purposes and its medicinal ability due to the presence of the secondary metabolites. (C) JASEM
\end{abstract}

https://dx.doi.org/10.4314/jasem.v21i5.19

Keywords: Timber, Hymenocardia acida, Functional group analysis, Phytochemical, thermal andchemical constituents.

Hymenocardia acida is a plant of the Phyllanthaceae family native to tropical Africa. In Nigeria, its Igbo name is ikalaga, orupa in Yoruba and janyaro in Hausa. It is a hardwood mostly located at Enugu and Awka (Arbonnier, 2004; Keay, 1989)

Hymenocardia acida is a deciduous shrub or small tree growing up to 10 metres tall, often looking gnarled and twisted with a characteristic rough rustyred bark. A tree of the tropics, found at elevations of $500-1,200$ metres, growing in areas that experience a long dry season. It succeeds on sandy, loam and clayey soils (Dressler et al.,2014).

The plant is especially valued for its medicinal virtues in Africa, where a decoction of the leaves, combined with honey, is used to treat coughs, stomach aches and biliousness. The vapour of the boiling leaves is inhaled to treat headache. The leaf powder is also added to food as a treatment for asthma. The plant also provides food, wood and tannins for local use and is sometimes planted to prevent soil erosion (Arbonnier, 2004). Its young leafy shoots could be used as a supplementary food, an acid flavor and the fruit is edible and is sometimes eaten. The bark, leaves, leafy shoots and roots have a considerable range of medicinal uses in Africa. In Kenya and in Uganda the wood is known for its hardness, denseness, durability and good resistance to termite-attack. It is used to make pestles and barkcloth mallets. (Desch and Dinwoodie, 1981)

Wood is a major building material that is renewable and replenish able in a continuous cycle. The demand for tropical woods is growing. Timber is a type of wood that has been processed into beams and planks used for structural purposes and, many other uses as well. Trees provide a huge variety of products for humanity. However, it is their timber that provides the greatest contribution in terms of income. (Arntzen, 1994) Different trees species provide timber with varying strength, durability, resonance, colour and scent. As a result, only certain tree species are suitable for a given purpose or end use, be it for building materials, veneers, furniture, musical instruments, and others. (Eboatu and Altine 1991) The global demand for timber has put huge pressure on the wild populations of particular tree species.

There are insufficient information on the wood of Hymenocardiaacida, therefore, some thermal and variable properties, chemical constituents, phytochemical and functional group assay of the wood were investigated, also determining its suitability. 


\section{MATERIALS AND METHOD}

Sample Collection and Identification: Hymenocardia acida timber was collected from timber shed at Awka in Awka North Local Government Area of Anambra State. Timber dealer, forest officer (Mr. Vin Okakpu of Nnewi Forestry) as well as literature (Keay et al.,1989) helped in the timber identification.

Sample Preparation: Hymenocardia acida timber was cut in a saw mill into two different shapes and sizes; dust from the timber was also collected. The timber was cut into splints of dimensions $30 \times 1.5 \times$ $0.5 \mathrm{~cm}$ and cubes of dimensions $2.5 \times 2.5 \times 2.5 \mathrm{~cm}$. The samples were dried in an oven at $105^{\circ} \mathrm{C}$ for 24 hours before the experiments.

Methods: Characterization of Thermal Properties: Afterglow time, flame duration, flame propagation, ignition time, oven dry density, moisture content, water imbibitions, ash percentage, specific gravity, porosity index, thermal conductivity and electrical conductivity were variously determined using American Society for testing and material (ASTM) methods (1998 \& 1999) and as described by Eboatu and Altine (1991). Each experiment was repeated three times and the results averaged. The microelement composition was analysed using atomic absorption spectrophotometer model PG 990 manufactured by PG instrument Ltd U.S.A.

Characterization of Phytochemical Constituents: resins, steroids, terpenoids, tanins, alkaloids, saponin, flavonoids, glycosides, phlobatannins, carbohydrate and protein were qualitatively and quantitatively determined by the methods outlined by Harbon (1998).

The hydrogen ion concentration $(\mathrm{PH})$ was determined by the method outlined by Amadi et al.(2004) using electrical PH meter PHS-25 made by Life Care England.

Characterization of Chemical Constituents: lignins, hemicellulose, cellulose, crude fibre, crude protein, carbohydrate, phenol and destructive distillation of the wood products were quantitatively determined by the methods outlined by Goering, Vansoest (1975), Oakley (1984) and Marzie (2010).

The chloroform-methanol and chloroform extracts were monitored using TLC, Fourier Transform Infrared and Ultraviolet Spectroscopic methods.

\section{RESULTS AND DISCUSSION}

The results of the solubility, physical, thermal investigations and the analysis of the active constituents present in the timber extract of Hymenocardia acida are given in tables 1-9.

\begin{tabular}{ll}
\multicolumn{1}{c}{ Table 1: Solubility Property of Hymenocardia acida Timber } \\
\hline \multicolumn{1}{c}{ Solvents } & Results \\
\hline Hot and cold water & Insoluble \\
$1.0 \mathrm{M}$ Dilute $\mathrm{HCl}$ & Insoluble \\
Concentrated $\mathrm{HCl}$ & Insoluble \\
Concentrated $\mathrm{HCl}+$ heat & Slightly Soluble \\
$1.0 \mathrm{M}$ Dilute $\mathrm{H}_{2} \mathrm{SO}_{4}$ & Slightly Soluble \\
Concentrated $\mathrm{H}_{2} \mathrm{SO}_{4}$ & Slightly Soluble \\
Concentrated $\mathrm{H}_{2} \mathrm{SO}_{4}+$ heat & Soluble \\
$1 \% \mathrm{NaOH}$ & Insoluble \\
Ethanol & Insoluble \\
Diethyl ether & Insoluble \\
\hline
\end{tabular}

The solubility analysis showed that Hymenocardia acida powder completely dissolved only in the presence of heated concentrated tetraoxosulphate (vi) acid. Therefore, the sample is resistant to polar, organic and corrosive substances except highly corrosive hot acid. This is in line with Petterson, (2007) who stated that chemicals are able to extract some extraneous materials in wood, yet woods are highly resistant to them and as such cannot be degraded by the chemicals.

Table 2: Thermal and physical characteristics of Hymenocardia acida Timber

\begin{tabular}{lll}
\hline Characteristics & Units & Results \\
\hline Afterglow time & $\mathrm{Sec}$ & 58.33 \\
Flame duration & $\mathrm{Sec}$ & 271.67 \\
Flame propagation rate & $\mathrm{cm} . \mathrm{s}^{-1}$ & $4.4 \times 10^{-2}$ \\
Ignition time & $\mathrm{Sec}$ & 3.67 \\
Over dry density & $\mathrm{g} . \mathrm{cm}^{-3}$ & $78.7 \times 10^{-2}$ \\
Moisture content & $\%$ & 12.67 \\
30 mins Water imbibitions & $\%$ & 11.1 \\
5 hrs Water imbibitions & $\%$ & 13.8 \\
24 hrs Water imbibitions & $\%$ & 22.3 \\
Ash Content & $\%$ & 0.95 \\
Thermal conductivity & $\mathrm{Umoh} / \mathrm{cm}$ & $14.37 \times 10^{2}$ \\
Electrical Conductivity & $\mathrm{Sm}^{-1}$ & $4.4 \times 10^{-3}$ \\
Specific Gravity & & 0.33 \\
Porosity Index & $\%$ & 1.90 \\
PH & & 6.55 \\
Colour & & Wheat \\
\hline
\end{tabular}

Thermal characteristics analysis showed that it had high flame duration value of 271.67 seconds which indicated that it could sustain itself till the whole length of wood got burnt. Afterglow time value of less than four minutes (58.33seconds) showed that it would not glow long enough for rekindle to take place as a result would be less hazardous in fire situations. A Flame propagation rate value of less than $0.28 \mathrm{~cm} . \mathrm{s}^{-1}$ indicated that the timber is firetolerant. Water imbibitions at $30 \mathrm{mins}, 5 \mathrm{hrs}$ and 24 hrs intervals with respective values of $11.1 \%, 13.8 \%$ and $22.3 \%$ showed the capacity of Hymenocardia acida wood to absorb water over a period of time (Udeozo, et al., 2014). The oven dry density and ash content values are in line with the ascertain of Desch 
and Dinwoodie (1981) which stated that dense and small ash content timbers are suitable in their use as a source of carbondioxide for internal combustion engine. The result indicated that Hymenocardia acida is a hardwood that will be very good for construction and other purposes.

Table 3: Phytochemical composition of Hymenocardia acida Timber

\begin{tabular}{lll}
\hline Class of phytocompounds & Inference \\
\hline Saponin & + & \\
Flavonoids & ++ & \\
Steroids & ++ & \\
Terpenoids & + & \\
Tannin & ++ & \\
Alkaloids & ++ & \\
Carbohydrate & + & \\
Protein & ++ & \\
Glycosides & + & \\
\hline Key: $+++=$ highly present; $++=$ moderately present; + & +
\end{tabular}

Phytochemical analysis revealed the presence of all the tested secondary metabolites which includes; flavonoids, alkaloids, saponin, protein, resins, tannin, steroids, terpenoids, glycosides and carbohydrate. The medicinal values of medicinal plants lie on these phytocompounds which produce definite physicological actions in human body. Flavonoids exhibit an anti-inflammatory, anti-allergic effects, analgesic and anti-oxidant properties (Dunguid, et $a l, .1989)$. The presence of alkaloids showed that it can be used as antimycotics and also in the treatment of stomach pains (Akpuaka, 2009). Saponin has been found to be anti-carcinogenic, cholesterol reducer and anti-inflammatory substance. Tanins are antiinflammatory, control gastritics and irritating bowel disorders, they also contribute to antimicrobial power which heals wounds and stop bleeding (Gills, 1992). Steroids are used in medicine for treatment of diseases. Terpenoids are associated with anti-cancer and also play a role in traditional and alternative medicine such as aromatherapy, antibacterial and other pharmaceutical functions. Resins are valued for their chemical properties and associated uses as the product of varnishes, adhesives and food glazing agents. Protein indicated high nutritional value of the extract, therefore can help in physical and mental growth and development (Dunguid et al., 1989)

Table 4: Micro elemental composition \% of Hymenocardia acida Timber

\begin{tabular}{ll}
\hline Zinc & 0.18 \\
\hline Lead & 0.43 \\
Cadmium & Nil \\
Copper & 0.01 \\
Sodium & 2.27 \\
Calcium & 0.31 \\
Magnesium & 0.01 \\
Potassium & 1.10 \\
Arsenic & 0.23 \\
Mercury & Nil \\
\hline
\end{tabular}

Atomic Absorption Spectrophometric analysis of the sample showed the presence of sodium, potassium, calcium, magnesium, copper and zinc which are beneficial to healthy adults at normal intake levels. Sodium and potassium play important role in maintenance of osmotic, electrolytic balance and proper rhythm of clothing (Tahiret al., 1999). Magnesium is for signaling the nervous system and also participates in osmotic and electrolyte balance but can cause genetic disorder (Konrad, and Weber, 2003). Copper is also involved in body enzymatic activities while zinc is required for growth, sexual development, wound healing infection, sense of taste and night vision in human (Maret and Sandstead, 2006). Lead and arsenic were also present while mercury and cadmium were absent.

Table 5: Quantitative Chemical Constituents of Hymenocardia acida Timber

\begin{tabular}{lll}
\hline Chemical Constituents & Units & Results \\
\hline Lignins & $\%$ & 23.0 \\
Hemicellulose & $\%$ & 28.0 \\
Cellulose & $\%$ & 46.0 \\
Crude Fibre & $\%$ & 0.9 \\
Crude Protein & $\%$ & 3.89 \\
Carbohydrate & $\mathrm{Mg} / \mathrm{g}$ & 1.09 \\
Phenol & $\mathrm{Mg} / \mathrm{g}$ & 1.94 \\
Tannin & $\mathrm{Mg} / 100 \mathrm{~g}$ & 860 \\
Alkaloids & $\%$ & 14.2 \\
Flavonoids & $\%$ & 8.2 \\
Saponins & $\%$ & 5.8 \\
Oxalate & $\mathrm{g} / 100 \mathrm{~g}$ & 1.0 \\
Total Acidity & $\mathrm{g} / 100 \mathrm{~cm}$ & 0.26 \\
Cyanogenic Glycoside & $\mathrm{Mg} / 100 \mathrm{~g}$ & 664 \\
Lipid & $\%$ & 5.6 \\
Wood Charcoal & $(\mathrm{g})$ & 2.5 \\
Pyroligneous acid & $\mathrm{cm}^{3}$ & 2.75 \\
Wood tar & $\mathrm{cm}^{3}$ & 0.2 \\
Wood gas & $\mathrm{cm}^{3}$ & 841 \\
\hline
\end{tabular}

Quantitative Chemical Constituents of Hymenocardia acida depicted that the sample contained $23 \%$ of lignin, $46 \%$ of cellulose, $28 \%$ of hemicelluloses and other parameters which help to confirm that the sample is a hard wood. Lignin is largely responsible for the strength, rigidity of plant and shields carbohydrate polymers from microbial and enzymatic attack. It contributes $20-25 \%$ of hardwood. Cellulose, a major chemical component of wood fibre wall, contributes $45-50 \%$ of hardwoods dry weight. Hemicellulose is a group of carbohydrate biopolymers that exist in close association with cellulose in the plant cell wall but it is less complex and easily hydrolysable (Arntzen, 1994; Desch and Dinwoodie 1996). The destructive distillation of Hymenocardia acida gave rise to four products in the following compositions; wood charcoal (2.5g), pyroligneous acid $\left(2.75 \mathrm{~cm}^{3}\right)$, wood tar $\left(0.2 \mathrm{~cm}^{3}\right)$ and wood gas $\left(841 \mathrm{~cm}^{3}\right)$. As wood reaches elevated 
temperatures, the different chemical components undergo the thermal degradation that affects the performance of wood. The extent of the changes depends on the temperature level and length of time exposed (White and Dietenberger, 2001). The thin layer chromatography of the chloroform and chloroform-methanol extracts showed three components with $\mathrm{R}_{\mathrm{f}}$ values of $0.7,0.6$ and 0.5 . The
TLC results confirmed the presence of some components and its high purity.

Table 6: Thin layer chromatographic characteristics of Hymenocardia acida Timber extract.

\begin{tabular}{lll}
\hline Sample & Number of spot & Rf value \\
\hline Chloroform-methanol extract. & 2 & $0.6 \& 0.5$ \\
Chloroform extract & 1 & 0.7 \\
\hline
\end{tabular}

Tables 7: Fourier Transformed Infrared and Ultraviolet spectra of Chloroform -methanol $1^{\text {st }}$ spot extract.

\begin{tabular}{ll}
\hline Wave number $\left(\mathbf{c m}^{-1}\right)$ & Suspected chromophores \\
\hline $\mathbf{3 4 2 4 . 7 3}$ & O-H stretch for alcohols, phenols and carboxylic acid \\
$\mathbf{2 8 5 6 . 6 7}$ & C-H stretch for alkanes and aromatics \\
$\mathbf{2 0 9 9 . 5 9}$ & C=N stretch for nitriles \\
$\mathbf{1 6 0 3 . 4 4}$ & C = O stretch for ketones, carboxylic acid, amides \& esters \\
$\mathbf{1 4 5 8 . 2 3}$ & C=C stretch for alkene and aromatic rings \\
$\mathbf{1 1 0 6 . 2 1}$ & C-O stretch for alcohols, esters and carboxylic acids \\
$\mathbf{1 0 1 7 . 4 8}$ & C-H deformation bonds for alkyl groups \\
UV max 218.50 and 285.50 & Indicating highly conjugated aromatic amide.. \\
\hline
\end{tabular}

Table 8: Fourier Transformed Infrared and Ultraviolet Spectra of Chloroform - methanol $2^{\text {nd }}$ spot extract.

\begin{tabular}{ll}
\hline Wave number $\left(\mathbf{c m}^{-1}\right)$ & Suspected chromophores \\
\hline $\mathbf{3 4 0 2 . 5 4}$ & O-H stretch for phenols and alcohols \\
$\mathbf{2 8 4 3 . 1 7}$ & C-H stretch for alkanes \\
$\mathbf{2 5 2 0 . 0 8}$ & C=N stretch for nitriles \\
$\mathbf{2 1 6 0 . 3 5}$ & C=N stretch for nitrile \\
$\mathbf{1 6 5 3 . 0 5}$ & C $=$ O stretch for ketones, acid amides and esters \\
$\mathbf{1 4 2 2 . 5 5}$ & C=C stretch for alkene and aromatics \\
$\mathbf{1 0 2 4 . 2 4}$ & C-H deformation bonds for alkyl groups \\
UV mpl 209.00 and 285.00 & Indicating highly conjugated aromatic amide \\
\hline
\end{tabular}

Table 9: Fourier Transformed Infrared and Ultraviolet Spectra for Hymenocardia acida Chloroform extract.

\begin{tabular}{ll}
\hline Wave number $\left(\mathbf{c m}^{-1}\right)$ & Suspected chromophores \\
\hline $\mathbf{3 4 4 0 . 1 6}$ & $\mathrm{O}-\mathrm{H}$ stretch for alcohols and phenols \\
$\mathbf{2 9 8 3 . 9 5}$ & $\mathrm{C}-\mathrm{H}$ stretch for alkanes and aromatics \\
$\mathbf{2 5 0 4 . 6 5}$ & $\mathrm{C}=\mathrm{N}$ stretch for nitriles \\
$\mathbf{2 1 1 8 . 8 7}$ & $\mathrm{C}=\mathrm{C}$ stretch for alkenes \\
$\mathbf{1 6 4 7 . 2 6}$ & $\mathrm{C}=\mathrm{O}$ stretch for ketones, acid amides \& esters \\
$\mathbf{1 4 1 6 . 7 6}$ & $\mathrm{C}=\mathrm{C}$ stretch for alkenes and aromatics \\
$\mathbf{1 1 0 4 . 2 8}$ & $\mathrm{C}-\mathrm{O}$ stretch for esters \\
$\mathbf{9 4 0 . 3 3}$ & $\mathrm{C}-\mathrm{H}$ deformation bond for alkyl and methyl groups \\
$\mathbf{U V}$ m $_{\text {f }} \mathbf{2 7 9 . 5 0}$ and $\mathbf{6 5 8 . 5 0}$ & Indicating highly conjugated trisubstituted aromatic compound. \\
\hline
\end{tabular}

From the FTIR and UV spectra of the isolated compounds, the bands observed are summarized in Tables 7-9. The O-H stretching bands at $3440.16 \mathrm{~cm}^{-1}$, $3424.73 \mathrm{~cm}^{-1}$ and $3402.54 \mathrm{~cm}^{-1}$ are of alcohols, carboxylic acid and phenols The O-H can be said to be associated. The $\mathrm{C}-\mathrm{H}$ stretching at $2983.95 \mathrm{~cm}^{-1}$, $2856.67 \mathrm{~cm}^{-1}$, and $2843.17 \mathrm{~cm}^{-1}$ corresponds to that of an aliphatic $\mathrm{C}-\mathrm{H}$. The $\mathrm{C}=\mathrm{N}$ absorption peak for nitriles appeared at $2504.65 \mathrm{~cm}^{-1}, 2099.59 \mathrm{~cm}^{-1}$ and $2160.35 \mathrm{~cm}^{-1}$. The $\mathrm{C}=\mathrm{O}$ stretching bands at $1603.44 \mathrm{~cm}^{-1}, 1647.26 \mathrm{~cm}^{-1}$ and $1653.05 \mathrm{~cm}^{-1}$ are that of ketones, acid amides, esters and carboxylic acids. The C-O absorption peak for alcohols, esters and carboxylic acids appeared at $1106.21 \mathrm{~cm}^{-1}$ and $1104.28 \mathrm{~cm}^{-1}$ while the $\mathrm{C}-\mathrm{H}$ deformation bonds for alkyl groups occurred at $940.33 \mathrm{~cm}^{-1}, 1017.48 \mathrm{~cm}^{-1}$ and $1024.24 \mathrm{~cm}^{-1}$. The absorption in the ultraviolet visible spectra and FTIR spectra suggested that the active compound might be 1, 2,3-trisubstituted aromatic compound with $\mathrm{O}-\mathrm{H}, \mathrm{C}=\mathrm{O}$, and $\mathrm{C}=\mathrm{N}$ groups attached.

Conclusion: The results of thermal and variable characteristics, phytochemical and AAS analysis of the timber, Hymenocardia acida had shown that it contained some components that could made it useful in animal feed formulation and as well a good material for various construction works. The UV and FTIR spectra showed that it contains some bioactive compounds. The presence of many secondary metabolites showed that Hymenocardia acida could be used in the cure and management of various diseases. Moreover, the complex chemical makeup of the timber showed the presence of cellulose, 
hemicelluloses, lignin and other components in the right proportion which confirmed that Hymenocardia acida is a fire resistant hardwood that could be very effective in various construction works.

\section{REFERENCES}

Akpuaka, M.U., (2009): Essential of Natural Products Chemistry, Mason Publishers, Inc. Enugu Nigeria, pp 34-65.

Amadi, B.A; Agomuo, E.N; Ibegbulam, C.O. (2004); Research Methods in Biochemistry, Supreme Publishers, Owerri.pp 90-115.

American Society for Testing and materials, 1998b. standard test methods for five tests of building construction and materials. Designation E119-98. West Conshohocken, PA: ASTM.

American Society for Testing and Materials 1999a. Direct moisture content measurement of wood and woodbased materials. Designation D4442-99. West ssConshohocken, PA: ASTM.

Arbonnier, M. (2004); Trees, Shrubs and Lianas of West Africa Dry Zones, Vol.1, grad, magrat publishers, p. 574

Arntzen, C.J. (1994); Wood Properties Encyclopedia of Agricultural Sciences. FI: Academic Press, Orlando. Pp 549-561.

Desch H.E; Dinwoodie J.M. (1981): Timber, its structure, properties and utilization, macmillian press ltd, London, $6^{\text {th }}$ Edition. pp $155-208$.

Desch H.E; Dinwoodie J.M. (1996): Timber, its structure, properties,conversion and use, macmillian press ltd, London, $7^{\text {th }}$ Edition. pp 306.

Dressler, S.; Schmidt, M.;Zizka, G. (2014)."Hymenocardia acida".African plants - a Photo Guide. Frankfurt/Main: ForschungsinstitutSenckenberg.

Dunguid, J.P; Marmoid, B.P; Swain, R.H.A. (1989): Mackie and Maccartney's Medical Microbiology $13^{\text {th }}$ ed, Vol. 1. Churchill Livingstone London, p163.

Eboatu, A.N; Altine, A.M; (1991): Studies on the Thermal Characteristics of Some Tropical Wood. Nigerian Journal of Renewable Energy. 12: 49-53

Gills, L.s. (1992): Ethnomedical uses of plants in Nigeria UNIBEN Press, Benin City, pp36-42.
Goering, H.D; Vansoest, P.J. (1975); Forage Fibre Analysis, Washington DC: U.S Dept of Agricultural Research Services. p 23

Harbon, J.B. (1998). Phytechemical method $3^{\text {rd }}$ edition.Thomson science 2-6 Boundary Row London, UK pp 1-290.

Keay, R W J. (1989); Trees of Nigeria.Clarendon Press Oxford. New York,pp 179-181.

Konrad, M; Weber, S.(2003); Recent advances in molecular genetics of hereditary magnesium-losing disorders, Journal of American Society, Nephrol. 14: 249-260.

Maret, W; Sandstead, H.H. (2006); Zinc requirement and the risks and benefits of zinc supplements, $\mathrm{J}$ Trace Elem Med Bio, 20: 3-18.

Marzieh, M.N; Marjan, M.N. (2010); Utilization of Sugar Beat Pulp as a Substrate for the Fungal Production of Cellulose and Bioethanol. African Journalof Microbiology Research, 4(23), 2556-2561.

Oakley, E.T.(1984); Determination of Cellulose Index of Tobacco Chemical Society 32: 1192-1194

Petterson, R.C. (2007); the Chemical Composition of Wood: The Chemistry of Solid Wood. Advances in Chemistry Series 207, Washington, DC.Pp 712- 718

Tahir, M.A., Chaudary, M., Rasool, M.R., Naeen, T.M., Chughtai, I.R.;Dhami, M.S.I. (1999); Quality of drinking water samples of Sialkot and Gujranwala, Proceedings of Tenth National Chemistry Conference. Pp 62-69.

Udeozo I.P., Eboatu A.N., Arinze, R.U., Okoye, H.N. (2011); some fire characteristics of fifty-two Nigerian Timbers. Anachem Journal Vol. 5 (1), 920-927

Udeozo I.P., Eboatu A.N., Kelle, I.H.,Ejukwa, E.E. (2014); Thermal characteristics, Phytochemical and Functional groups Assessment of Garciniankola as a Tropical Timber.IOSR Journal of Applied Chemistry. 7(10), 73-75.

White, R.H; Dietenberger, M.A. (2001); Wood Productions: Thermal Degradation and Fire. Encyclopedia of Material Science and Technology.E/Science Ltd, Washington, DC.PP 97129716. 